\title{
Lower Respiratory Tract Infection
}

National Cancer Institute

\section{Source}

National Cancer Institute. Lower Respiratory Tract Infection. NCI Thesaurus. Code C35158.

An acute or chronic, viral or bacterial infectious process that affects the lower respiratory tract. 